原

著

サケ科魚類咽頭の歯の分布について

\author{
橋本巌 後藤 仁 敏 \\ 小寺春人井上孝二 \\ 鶴見大学歯学部解剖学教室
}

(1976年 7 月 17 日受付)

\title{
The Distribution of the Teeth in the Pharynx of Salmonid Fishes
}

\author{
Iwao Hashimoto, Masatoshi Goto, Haruto Kodera and Kouji Inoue
}

Department of Anatomy, School of Dental Medicine, Tsurumi University

\begin{abstract}
要旨：サケ科魚類の口腔に歯が多数分布しているととはよく知られているが，著者らはニジマスでは咽頭 にも咽頭菌と鰓耙骨茵（鰓亏面の鰓耙にあり，鰓耙骨に植立する）の 2 群の歯があるてとをみて報告してき た。ととでは, とのような菌が他のサケ科 3 属 5 種（サケ属ヒメマスとヤマメ，ニジマス属ブラウンマス， イワナ属イワナとカワマス) にも分布しているかどうかを検索した。口腔から消化管起始部まで, X線撮影 や alizarin red 染色等を行って内腔面を精査し, また光顕組織標本を作製して鏡検した。その結果, 咽頭 に上下の咽頭歯群と多数の鰓耙骨歯が認められた。乙れらの歯は口腔の歯と同様, 円錐形で均質な象牙質か らなり, 多生歯性で, ただ微細な鰓耙骨歯だけは歯堤の出現なしに形成されるなど, ニジマスと同様であっ た。結論として, てれらの淡水産マス類では口腔と咽頭に同様の霜が共通してみられ, 分布状態もほとんど 同様であるが属により若干差異がみられた。
\end{abstract}

\section{I. 緒 言}

サケ科魚類の口腔に雬が多数みられるととはよ く知られており，その分布状態について記載され ている1,2)。しかし，咽頭にも雨があるととはあ まり知られていない。著者らはニジマスで咽頭に 2 群の䨑が分布しているととを最近報告した ${ }^{3,4)}$ 。 その 1 つは咽頭雬で，国外の文献に記載されては いるが，鰓弓骨格の観察の際，咽頭骨とともに簡 単に触れられているにすぎない5,6)。他の 1 つは 鰓弓面の鰓耙にある微細な雬で, 著者らは組織所 見から鰓耙骨歯と呼ぶのが適切と考えているせ。
太田はサケ・マス類の鰓耙の表面観察でてれを鋸 雨と記載している7)。従来, 硬骨魚類のなかには その外観から, 鰓耙に小棘をもつものがあると記 載されているものがあるが8 10)，これらの小棘は， 組織構造からみればニジマスの鰓耙骨䨑に相当す るものと思われる4。咽頭歯とともにその分布に 興味をひかれたので, 今回ニジマスに近縁のサケ 科 3 属 5 種の淡水産マス類について, 咽頭の歯の 分布について検索した。

\section{II. 材料と方法}

材料はサケ属のヤマメ Oncorhynchus masou 
(BREVOORT) とヒメマス O. nérke(WALBAUM), ニジマス属のブラウンマスS Salmo trutta (LINNÉ) およびイワナ属のイワナSalvelinus pulvius (HILGENDORF) とカワマス S. fontinalis (MITCHILL) のマス類 5 種で, 種々の大きさのものを $10 \%$ ホル マリンに固定後, 観察した。

観察方法はニジマスの場合と同様( ${ }^{4)}$ ，口腔か ら胃の噴門部まで内腔を開いて，菌の分布状態を 粘膜面から精査した。また $3 \% \mathrm{KOH}$ 亿浸漬後,
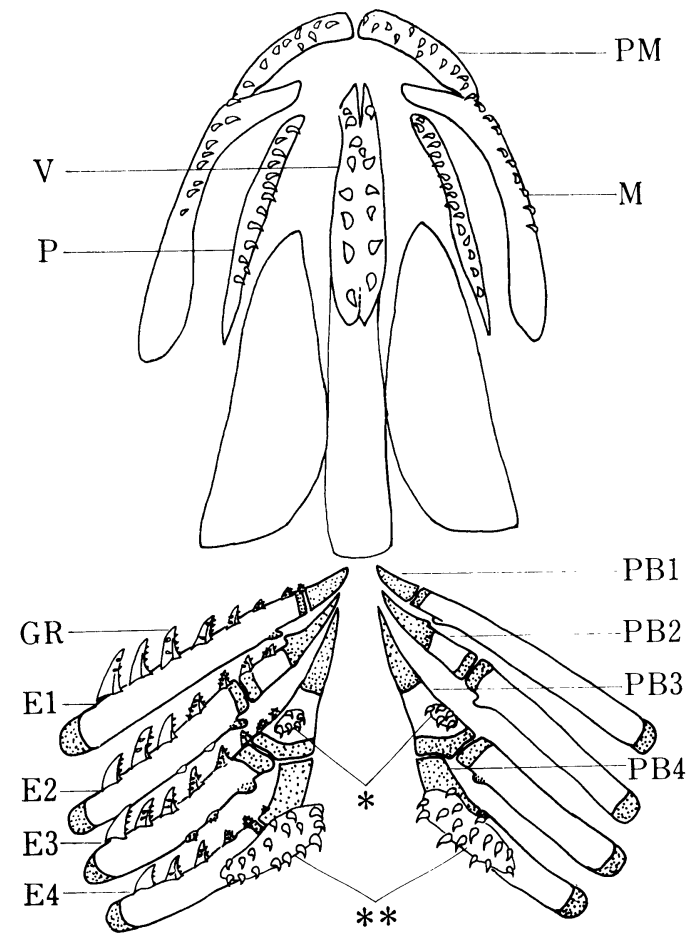

図 1-A（ヤマメ，上半） alizarin red の一塊染色を行って骨との関係を実 体顕微鏡で観察した。Softex ESM 型により撮 影したX線写真の観察も補助的に行った。

一方, 全長 $10 \mathrm{~cm}$ 前後の材料们つて, 脱灰組 織標本を作製し，ヘマトキシリン・エオジン染色 とアザン染色を行って鏡検した。

以上の方法により，口空の歯を対照しながら， 口腔後方に菌を検索した。

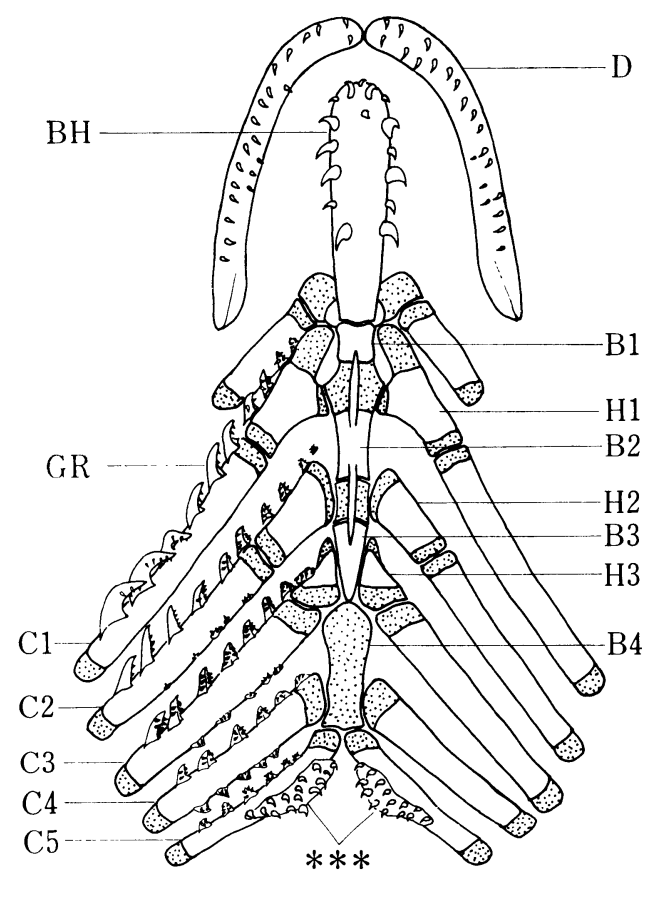

図1-B（ヤマメ，下半）

図 1 ～図 5 マス 5 種の雬の分布と骨格との関係（alizarin red 染色標本による）。

図 1 ヤマメ (全長120mm)

図 2 ヒメマス (全長 $265 \mathrm{~mm}$, 体重 $183 \mathrm{~g}$ )

図 3 ブラウンマス（全長 $340 \mathrm{~mm}$, 体重 $755 \mathrm{~g}$ ) 図 4 イワナ（全長 $290 \mathrm{~mm}$, 体重 $455 \mathrm{~g}$ )

図 5 カワマス (全長 $370 \mathrm{~mm}$, 体重 $940 \mathrm{~g}$ ).

一側では鰓吧骨と鰓耙骨歯を示していない。点描の部分は骨化していないととろ。

$\mathrm{A} ：$ 口腔と咽頭腔を腹側からみたとてろ。

$\mathrm{PM}$ : 上顎歯と前上顎骨

$P$ : 口蓋骨歯と口蓋骨

$\mathrm{M}$ : 上顎歯と上顎骨

V : 䤮骨歯と鋤骨

GR : 鰓耙骨歯と鰓秄骨

$\mathrm{E} 1-4:$ 第 1 ～第 4 上鰓骨

PB1-4 : 第 1 第 4 咽鰓骨 $*$ : 前上咽頭歯と前上咽頭骨 $* *$ : 後上咽頭歯と後上咽頭骨

$B ：$ 口腔と咽頭腔を背側からみたととろ。

$\mathrm{D}$ : 下顎歯と歯骨 $\mathrm{BH}$ : 舌歯と基舌骨 $\mathrm{GR}$ : 鰓耙骨歯と鰓耙骨

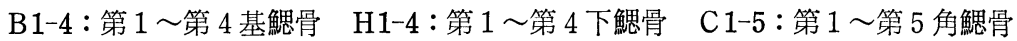

***：（後）下咽頭雬と（後）下咽頭骨 **** : 前, 中下咽頭歯と前, 中下咽頭骨 


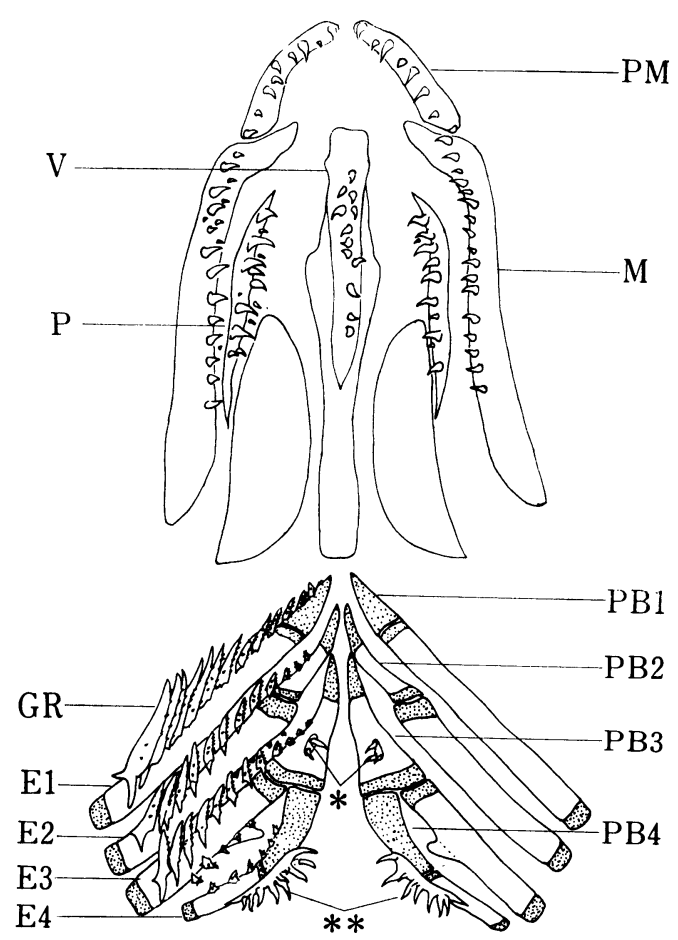

図 2-A（ヒメマス，上半）

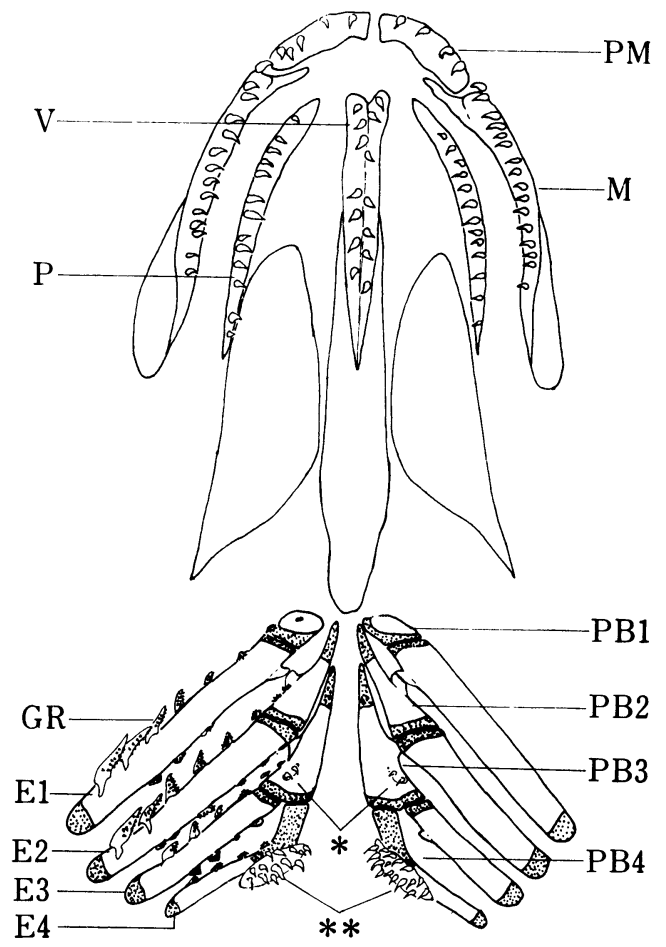

図 3-A（ブラウンマス，上半）

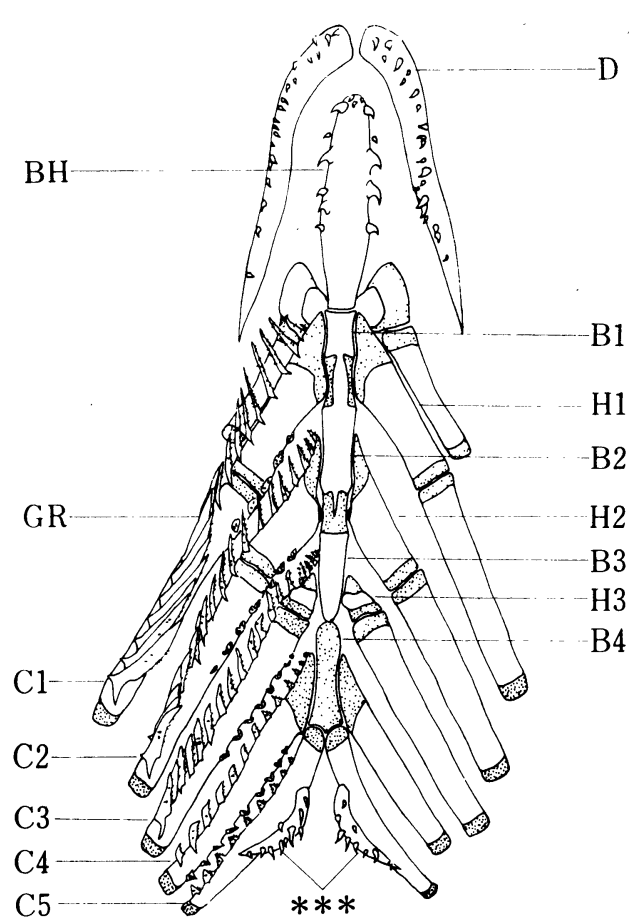

図 2-B (ヒメマス, 下半)

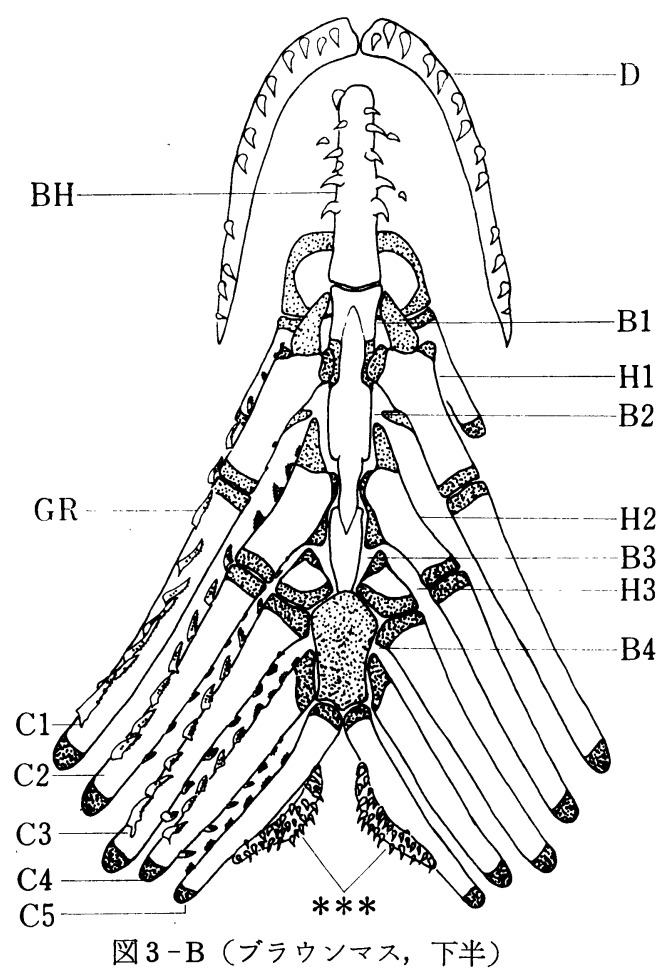




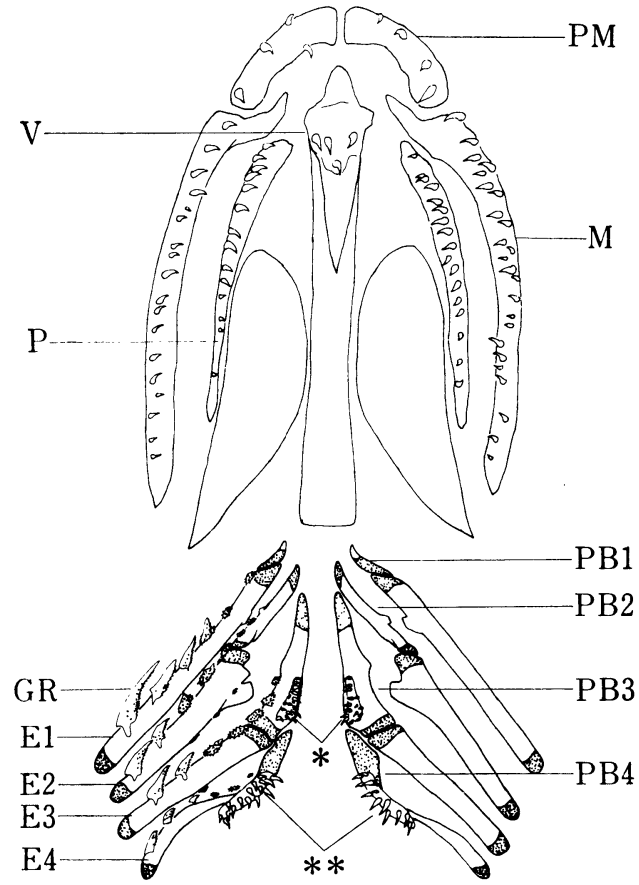

図 4-A（イワナ，上半）

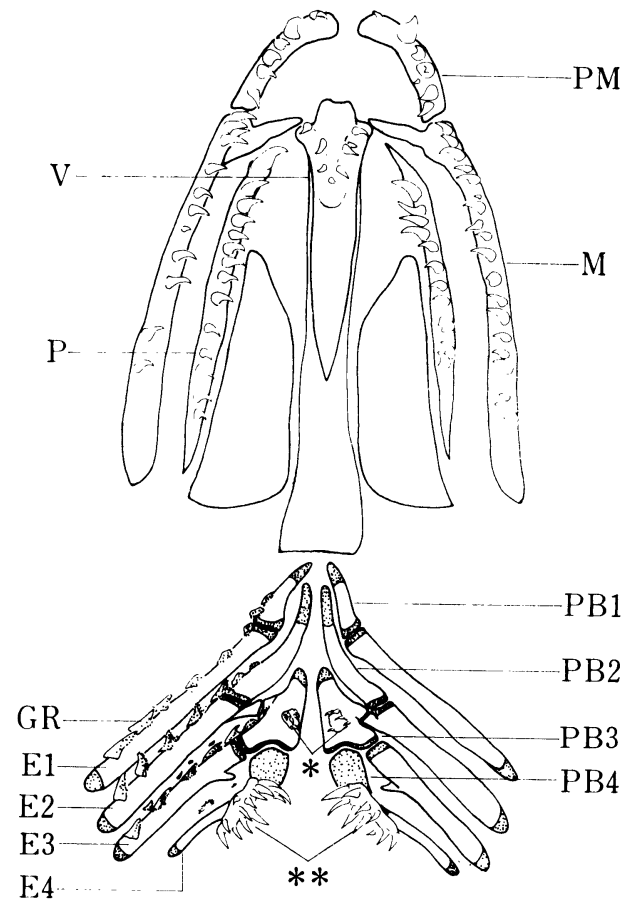

図 5-A（カワマス, 上半）

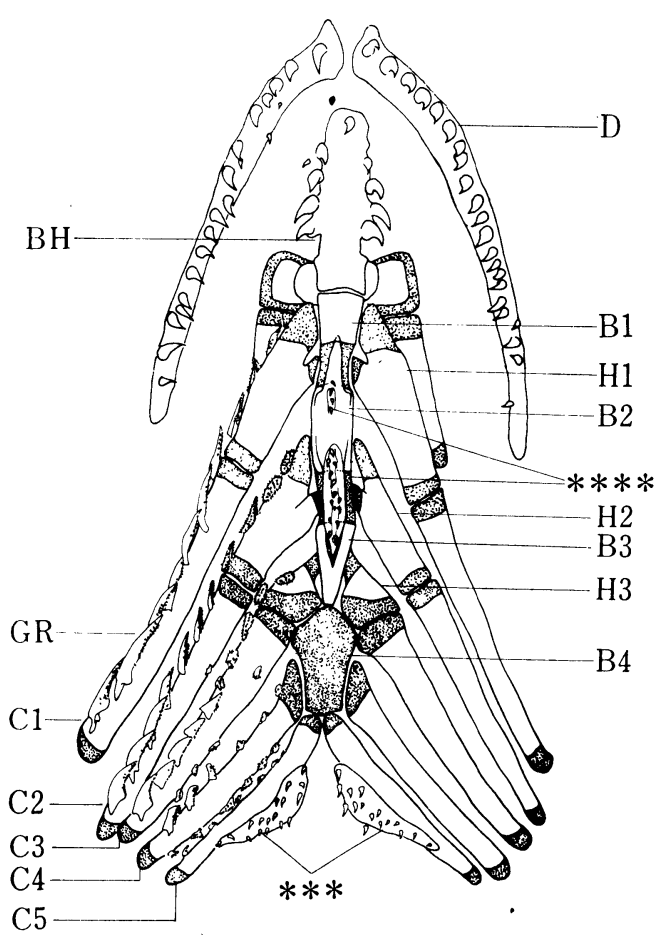

図 4-B (イワナ, 下半)

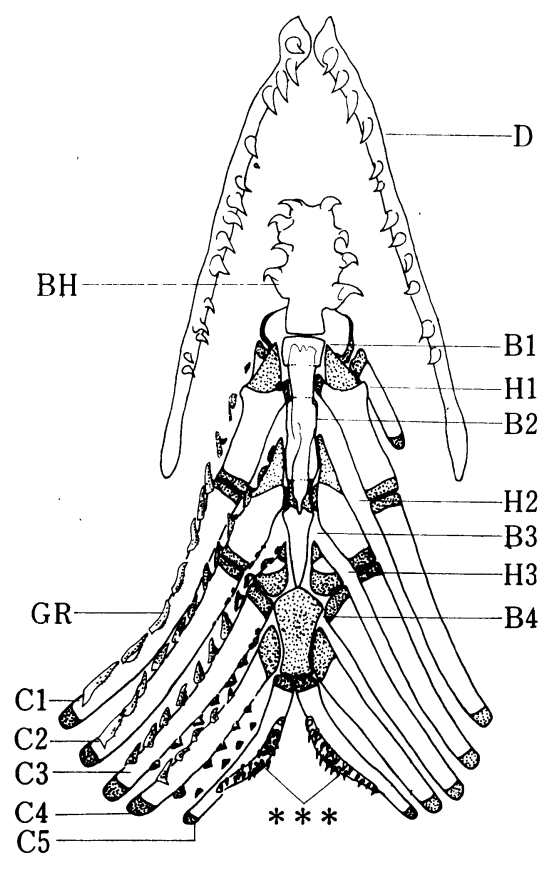

図 5-B（カワマス，下半） 


\section{III. 観 察 所 見}

サヶ科 3 属 5 種のマスでは, 歯は口腔と咽頭に 多数分布し食道とその後方にはない。図 1 〜図 5 に歯の分布をalizarin redの染色標本にもとづい て，植立する骨とともに示した。

てれを通覧すると, 口腔の歯は所属する骨に歯 列をつくっているが，咽頭の歯は歯列をつくらず 本来の鰓弓骨格の上にある小さい骨に群生してい る。そして口腔と咽頭の歯の分布状態は 3 属 5 種 にほぼ共通していることがわかる。

口腔の上壁には上顎菌が対性の前上顎骨 (PM) と上顎骨 (M) に, 口蓋骨雨は対性の口蓋骨 (P) に，鋤骨柬は不対性の鋤骨（V) に植立してそれ ぞれ歯列を形成している。下壁では下顎雬が対性 の歯骨 (D) に, 舌歯が不対性の基舌骨 (BH) の辺縁にならんでいる。乙のうち鋤骨曾の畨列は 鋤骨の形態とともに 3 属または属内で異なり, 従 来分類形質の 1 つに挙げられている ${ }^{1,2)}$ ととが了 解される。すなわち，イワナ属（図4-A，5一 A）では䤮骨前方部のV字形の隆起に沿って，V 字形の歯列がある。サケ属とニジマス属では䤢骨 は長く，その全長にわたって米列が形成されてい る。歯列はヒメマス（図 $2-\mathrm{A}$ ) では不規則では あるがほほ1列である。ブラウンマス（図 $3-$ A）では鋤骨の正中に溝があり，歯はその両側で 左右のものが前後に交互に配列し 2 列性の歯列を つくっている。ヤマメ（図 1-A）では鉫骨の前 後両端の正中に切れてみがあり，また X 線写真 （図 9 ）には乙の正中に透過像と不透過像がみら れるととから，ての部に溝をもつブラウンマスと 全く溝のないヒメマスの中間型の鋤骨の観を呈す る。ヤマメでは䤢骨歯の歯列は 2 列性である。

次に，咽頭の歯とその植立する骨の所見に入る まえに，咽頭の骨格すなわち鰓弓骨格の構成をみ ると， 5 種のマスに共通して 5 つの有対の部分と 下壁の正中の無対の小部分からなる。前者は第 1 〜第 3 鰓弓では骨化した下鰓骨 (H1-3), 角鰓骨 (C1-3), 上鰓骨 (E1-3) および咽鰓骨 (PB13 ) の 4 種類の骨で構成されている。第 4 鰓弓で
は 3 種類の骨からなり，角鰓骨（C 4) と上鰓骨 （E 4）だけが骨化し，第 4 咽鰓骨 (PB 4) は軟 骨性である。第 5 鰓弓の骨格は角鰓骨 (C 5 ) だ けからなる。無対のものは正中線上に前後になら ぶ 4 つの基鰓骨（B 1-4）からなり，第 4 基鰓骨

（B 4) は軟骨性である。

てれらの鰓马の骨に，歯を植立させている小さ い骨すなわち咽頭骨と鰓耙骨が付属している。前 者は薄板状で第 3 第 5 鰓弓の骨の内側寄りに数 対あり，咽頭歯を植立させている。後者は基鰓骨 を除く鰓弓の骨の前縁または後縁に多数ならんで おり，鰓耙の支柱であってその外形は鰓耙の縮小 形に近く，てれに鰓耙骨菌が植立している。咽 頭柬と鰓耙骨菌の分布状態は 3 属 5 種にほとんど 共通しているが，属により若干の差異もみられ た。

\section{1. 咽頭歯の分布状態}

5 種のマスに共通して, 咽頭上壁に 2 対の前後 の上咽頭畨群と下壁に 1 対の下咽頭歯群がある。 イワナではこのほか, 下壁の正中部の基鰓骨上に も分布している。

前上咽頭歯群 : 第 3 咽鰓骨(PB3)上の前上咽頭 骨に植立する。他の咽頭歯群より囦数は少ない。 左右ほぼ同数でその合計はニジマス属のブラウン マス 4 本, サケ属のヒメマス 5 本, ヤマメ 10 本, イワナ属のカワマス12本, イワナ32本の順で多い。 菌数に応して前上咽頭骨の大きさに大小がみられ る。ブラウンマスでは咽頭骨は内側縁を除き，咽 鰓骨に移行し痛合している（図 $3-\mathrm{A}$ )。イワナ 属では他の 4 種にくらべ, 咽頭骨が咽鰓骨の内側 に编っている。

後上咽頭蒾群: 後上咽頭骨に群生している。乙 の咽頭骨は外側縁と第 4 咽鰓骨（PB4，軟骨性） と第 4 上鰓骨（E 4) の両方にまたがってのって いる。ヒメマスでは咽頭骨は肥厚して細長く, 植 立する柬は他のマスより強大でかつ少ない（図 13)。

下咽頭菌群 : 多数の歯が第 5 角鰓骨 (C 5 ) の 上に外側縁をのせた下咽頭骨に植立している。乙 の咽頭骨は内側に凸彎して弧状を呈し, 後上咽頭 
骨と同大かやや大きい。

イワナでは基鰓骨上で正中線上に, 細長い薄板 状の骨があって，乙てにも雬が分布している（図 $4-\mathrm{B}$, 図19，20）。霜は前後の 2 群に分けられ， 前方の前下咽頭歯は 4 本が 1 列にならび，その前 端の 1 本は第 2 基鰓骨（B 2 ）の前方に向かう剣 状の突起の基部に, 後に続く 3 本は薄板状の前下 咽頭骨に植立している。後方の中下咽頭菌は14本 数えられ，第 2 基鰓骨（B 2 ）と第 3 基鰓骨（B 3 ）を橋渡しする細長い薄板状の中下咽頭骨に植 立している。霜はジグザグに前後に交互にずれて 配列して，全体として 2 列を作っている。基鰓骨 上のこの薄板状の骨は部分的に基鰓骨と瘾合して いる。乙れに植立する菌は後方食道側に植立方向 をとっている。

次に, 咽頭粘膜面をみると, 前半は各鰓马骨格 に相当した鰓面からなり鰓腔部ともいわれる。 後半部は最後の鰓弓骨格が支柱となり, 食道へ続 くひとつづきの粘膜に被われている。前上咽頭蒾 は第 3 鰓弓咽頭面の正中寄りの部位に, 後上咽頭 蒾群は咽頭後半部の前方部に位置する。下咽頭 歯群は後上咽頭蒾群に対向する下面にみられる

（図 7，8，11，12）。イワナでは基鰓骨上の柬 は下面の正中部で，第 1 鰓弓相当部の後半之第 2 鰓弓に相当する領域にみられる。粘膜面では萌出 菌の数は alizarin red の標本で数えられるより 少なく, 各咽頭蒾群はその部の粘膜下に, 硬組織 形成中の未萌出霜を同数近くともなっているとと がわかる。萌出菊は粘膜の溝の中で（図 7,8）, 食道側に植立方向をとって傾斜しており，尖端だ けを露呈している。前上咽頭雬はヒメマスやブラ ウンマスの場合のように, 粘膜面の観察では萌出 歯としては認められないてともある(図11)。

\section{2. 鰓耙骨歯の分布状態}

マス類の咽頭腔前半の鰓腔部には, 鰓弓面から 鰓裂に向かう小突起がならんでいる（図 7，8）。 この突起が鰓耙で, 各鰓弓面の前縁のものは発達 している。後縁のものは小さく, マスの種類によ り第 1 , 第 2 鰓弓では存在しない（図 $7,8,11$ 12）。鰓耙は正中部を除いて鰓亏の上面から側方
隅角部をへて下面へ櫛の歯のようにならび，外側 隅角部では大きく，正中部に近いもの程小さい。 隅角部付近の，とくに前方の鰓可鰓耙は細是く 大きい。乙のような大きい鰓耙では, 肉眼でも内 側縁が鋸歯状に，または棘のような微細な突起す なわち小棘がいくつもあるようにみえるてとがあ る。乙の鋸の刃または小棘の一つ一つが鰓耙骨歯 である。太田 ${ }^{7}$ は表面の拡大観察（彼の図による と 5 倍大）でてれを鋸歯とよんでいる。組織標本 の観察では鰓耙骨蔝はほとんど粘膜上皮に被われ て, 表面に露呈しているのは歯の尖端部だけであ る。乙の微細な雬は alizarin red 染色標本で は, 円錐形を呈し各鰓耙の支柱の鰓耙骨に多数放 射状に植立しているてとがわかる。表面観察より 歯数が多いのは萌出菌と硬組織形成中の未萌出歯 とがみえるからである。X線写真では口腔の曾や 咽頭菌と同様に, 明らかにX線不透過像として観 察される。

鰓耙骨は鰓耙の外形を縮小した種々の形態を示 す。小さいものはわずかに盛り上がったてぶ状や 半球犬で（図15２0）, やや大きくなると半円錐 状または三角錐状（図15２0）を呈し，大きいも のは細長くのび出した三角板状（図13～19）であ る。乙れらの形態之大きさには，各鰓马面の正中 側から外側一鰓耙骨の位置がずれるにともなって 移行がみられる。また, 鰓耙骨は鰓马の骨に対し

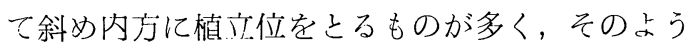
な鰓耙骨の内側面には骨が形成さ机ていない。乙 の部分は alizarin red の標本では着色せず白く 抜け一みえる（図15の細い矢印，図16）。大きい 鰓耙骨の基底には前後に脚があって, 鰓马骨にま たがるようにのっている（図12の細い矢印）。両 者の骨が瘺合することはなく, 粘膜をはがしてゆ くと, 鰓耙骨は粘膜側についてくる。鰓耙骨（ま たは鰓耙）の数, 大きさ, 形態はマスの種類によ って異なる。ヒメマスでは細長い三角板状のもの が多く密に分布し（図 $2-A, B$, 図11１4）, 次に数の多いブラウンマスでは低い半球状のもの から，半円錐状，三角板状のものがみられる（図 $3-\mathrm{A}, \mathrm{B}$, 図11, 12, 15)。ヤマメとカワマス 
では数も減少して前者では低い三角錐状のものが 中間型として多くみら机（図 1-A，B，図7，

8)，イワナでは数は最も少なくなり（図 4-A, $\mathrm{B}$, 図11, 12, 17〜20), その形態はカワマス(図 5 -A，B，図10，11，16）と似ており，低い半 球状のものが多く, 半円錐状から三角板状のもの へ移行している。

鰓耙骨の大きさと形態は多様であるが, 鰓秄骨 歯は大きい鰓耙骨を除けばほぼ全面に分布し，鰓 耙骨の大小による歯の大きさの差異はあまりみら （咽頭腔側）（鰓裂側）

（咽頭腔側）（鰓裂側）

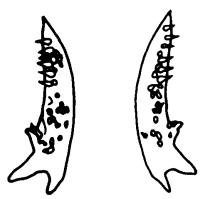

ヤマメ

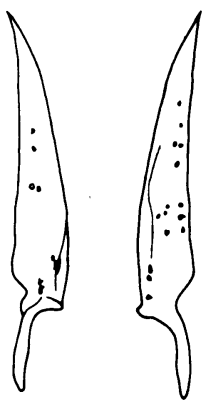

ヒメマス
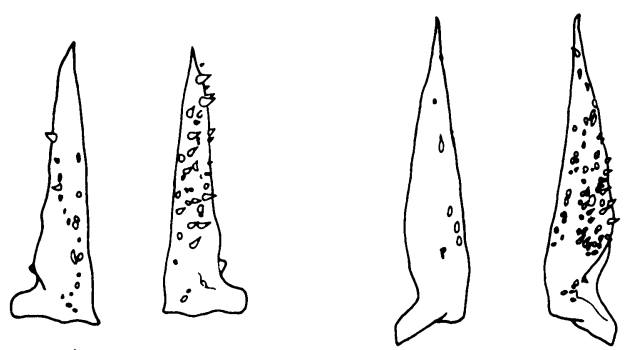

ニジマス
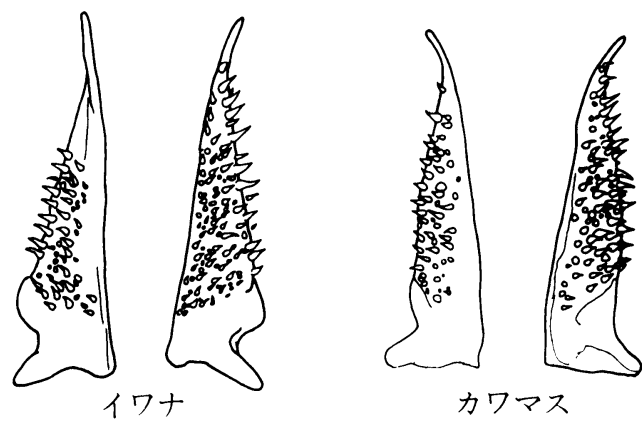

カワマス

図 6 鳃耙骨菌の分布状態

第 1 鰓亏咽頭面隅角部の鰓耙で，咽頭腔側の面と 鰓裂側の面とでの比較。原図 $\times 50$ 。
れない。また鰓耙骨の内側面の骨を欠く部分には 菊は分布していないが，その部分を除いて鰓耙骨 歯は全体として放射状沿上に密生している。し かし, 鰓弓隅角部の三角板状の大きい鰓耙骨を拡 大してみると（図21），鰓耙骨䨑は骨の内側縁に 沿って配列しており，外側縁とその付近や尖端の 骨の部分には分布していない。第 1 鰓弓隅角部の 鰓耙骨で歯の分布を魚種間で，また，鰓耙骨の咽 頭腔側の面とその裏面すなわち鰓裂側の面で比較 すると，分布状態に差異がみられる（図6）。鰓 耙骨菌の数も5 種の間で一様でないが，咽頭腔側 の面より裏面の方が多い傾向がみられる。サケ属 のヒメマスでは鰓耙骨菌は極めて少なく, 裏面で は咽頭腔側の面よりわずかに多い。同に゙属のヤマ メでは両面にほぼ同数分布している。その歯も鰓 耙骨の大きさからみれば小さくない。ニジマス属 では菌は小さく, 鰓耙骨の表裏両面での歯数の差 は著明で，ブラウンマスよりニジマスでは董面に 多数分布している。イワナ属では両面とも歯数が 多いが，董面では外側緑近くまで密に分布してい る。表面の咽頭腔側の面では外側縁 1/3 の範囲に は隶は存在しない。またその内側縁近くの粷は大 きく外側縁に近づくにつれて微細となっている。

\section{3. 咽頭の歯の組織所見}

3 属 5 種のマスではいずれも咽頭菡と鰓耙骨茵 の大きさに著しい差がみられるが, 両者の組織構 造は各種類とも先に報告したニジマスの場合と同 様であり，また口腔の歯のそれとも一致する共通 の所見を示した。すなわち, 象牙細管を欠く均質 無構造の象牙質と霜髄からなり，霜足骨により基 底の骨（咽頭骨または鰓耙骨）に瘺合し，その結 合様式は端生性である（図22～24）。図23はイワ ナの咽頭底正中線上の咽頭菌で, 基底の咽頭骨は 基鰓骨の表層骨化部との間に瘾合がみられる。

咽頭の歯は口腔のそれと同様多生雪性である。 ただその初期発生において, 鰓耙骨歯では柬堤が 形成されないが，その同じ個体の咽頭歯や口腔の 歯では歯堤がみられる。鰓耙骨歯の歯胚は粘膜上 皮肥厚部と結合組織の境界域に形成される（図 24)。粘膜上皮肥厚部の基奃細胞が立方ないし円 
柱状となり，粘膜表面側へ向かって彎入してきて 内エナメル上皮が形成される。ての彎入したとて ろに間葉細胞が集積して歯乳頭となる。内エナメ ル上皮の彎入した辺縁すなわち粘膜重層扁平上皮 の基底細胞層に移行する付近では，歯肧上皮が間 葉へ向かって肥厚を示し，乙れが歯压上皮の増殖 端となって菌胚は杯状から鐘状に形態をかえる。 これにともない, 内エナメル上皮はエナメル芽細 胞に分化し，また茵乳頭から象牙芽細胞が分化し て象牙質が形成されてくる。乙の過程に歯堤は出 現せず，䨑塵上皮（内エナメル上皮またはエナメ ル芽細胞）はその粘膜表面側を重層扁平上皮の細 胞に裏づけられたまま歯の形成が進行する。外工 ナメル上皮は歯胚上皮の増殖端の部分でのみ認め られる。

\section{IV. 考察}

今回観察した淡水産マス 5 種の咽頭には咽頭画 と鰓耙骨歯が分布しており，ての 2 群の歯の分布 状態, 組織構造, 発生についての所見はさきに報 告したニジマスの場合3,4) とほぼ同様であった。 しかし，雪の分布状態には魚種によって若干差異 がみられた。

咽頭迷には 2 対の上咽頭菊群と 1 対の下咽頭菌 群が共通してみられるが，イワナではてのほかに 咽頭底の正中部にも観察された。その雬は他の咽 頭菌と同様に，鰓弓骨上の薄い板状の骨に植立し ており，植立方向を食道側に向けている。したが って雬は咽頭歯群であり，その植立する薄板状の 骨は咽頭骨と同定される。イワナの下咽頭曾群は 最後の第 5 鰓弓に分布するものを後下咽頭雬群と し，正中線上のものを前後の $2 つ$ 部分にわけ て, 前下咽頭歯群, 中下咽頭歯群とすることもで きる。

Norden ${ }^{6)}$ はカワマスでこの基鰓骨に関連して みられる骨を basibranchial plate と記載し, 他 の咽頭骨 pharyngeal plate と区別している。 そしてカワマスでは basibranchial plate には 歯が存在することも無い場合もあると記してい る。著者らはこの薄板状の骨をカワマスでも観察
しているが，歯は分布していなかった。基鰓骨上 の骨については他のマス類でも第 2 基鰓骨の前後 から, 剣状の小突起がそれぞれ第 1 と第 3 基鰓骨 に突出している。しかしその上に霜は分布してい ない。ニジマス属で同様のものを Tchernavin ${ }^{5)}$ は supracopulary anterior, supracopulary posterior と記載し，マスの種類によって第 3 基 鰓骨と痛合したり、癒合しないものがあると述べ ている。著者らはイワナの組織慓本で（図23）, この板状の骨 (咽頭骨) が基鰓骨の骨化部と部分 的に痛合しているのをみている。

次に, 2 対の上咽頭歯群のうち, 前上咽頭歯群 ではマスの種類により他の咽頭霜群にくらべ雪数 にばらつきが目立つ。ニシマス属, サケ属では一側 に2〜 5 本であったが, イワナ属ではその $3 \sim 4$ 倍もの歯数が観察されそれだけ咽頭骨も大きい。

Norden ${ }^{6)}$ もカワマスでは橉数の多いてとを指摘 している。な打前上咽頭骨と第 3 咽鰓骨の痹合 の有無について, ニジマ属ではTchernavin が Salmo salar LINNAEUs では $1 \sim 3$ 本の前上 咽頭歯は第 3 咽鰓骨に直接植立しており, 咽頭骨 は乙てにはないと記している。著者らはニジマス Salmo gairdneri irideus GIBBONS でこの咽頭 骨と第 3 咽鰓骨の瘺合を組織所見で確かめている が，今回のブラウンマスでは両者の骨の癒合は肉 眼的にもニジマスより顕著であった。

鰓耙骨歯については，太田てはこれを鰓耙の表 面観察で鋸茵とよび，サケ・マス類10種で分布を みている。鋸菌は魚種により鰓耙の数と形態が異 なるのにともなって分布状態に差異があると報告 している。すなわち, 鋸蒾は鰓耙が太く短く数が 少ないものでは発達し, 鰓耙が長く数の多いもの では鋸歯は非常に小さく数も減少していると述 べ，サケでは鋸椈は存在しないと報告している。 著者らは鰓耙骨と鰓耙骨茵の関係を観察した。鰓 耙骨が大きく三角板状のものでは鰓耙骨曾の分布 は太田の所見と同样である。鰓耙骨が小さく半球 状のものや半円錐形,三角錐状の短いものでは,ほ ぼ全面に鰓耙骨歯が分布している。鰓耙骨が多様 でも鰓耙骨絪の大きさはての場合ほぼ一様で格別 
に小さくはない。また鰓耙骨には骨の形成されな い結合組織の部分があり，その面または縁には歯 は植立していない。また，鰓弓隅角部の大きい三 角板状の鰓耙骨ではその咽頭腔側の面と裏面の鰓 裂側の面とでは, 鰓耙骨菌の分布に差があり（ヤ マメを除く）後者の面の方が蒌数が多い。両面と も外側縁近くになると茵は存在せず，内側緑に近 づく注ど鰓耙骨茵は大きく，曻側緑に近づくほど 小さい菌が分布している。

著者らはニジマスの観察の際3,4,14), 他の魚類 の鰓耙にみられる小棘は組織構造上, 歯であろう と推測したが，今回のマス 5 種では央証された。 タイ等他の魚類についててれを裏付ける記載もみ られる11 13)。

Nelson $^{15,16)}$ はニシン科魚類の鰓弓の諸構造物 について比較観察を行い，分類体系に言及してい る。そのなかで（咽頭）歯とその植立する（咽 頭）骨には合併と退化消失の傾向が，また歯の植 立する骨と鰓弓の骨格の間には癒合の傾向が系統 発生学的にみられるとし，その部位として基鰓骨 と咽鰓骨の領域をあげている。著者らの観察した マス類 5 種の咽頭蒾の分布状態には, 上述のよう に魚種の間に一見雑然とした差異がいくつか指摘 されるが，乙れを Nelson の系統発生学的観点 からみると進化の過程の種々の段階として整理で きるように思われる。そして咽頭蒾についてはイ ワナ属, なかでもイワナは他のマス 4 種よりも進 化の度合の低いところに位置づけられる。Nelson はまたニシン科では，鰓耙は microphagus habit の傾向にともない増加してくることを述べて いるが，鰓耙骨雬については触れていない。

\section{V. 結 論}

サケ科 3 属 5 種の淡水産マスについて, 歯の分 布状態を観察し, 口腔と咽頭に多数の菌を認め, さきに報告したニシャスの場合とほほ同様の所見 を得た。また咽頭の歯の分布には 3 属 5 種の間に 若干の差異もみられた。

1. 咽頭には咽頭骨と鰓耙骨歯が分布してい る。
2. 咽頭䨑には 2 対の上咽頭菌群と 1 対の下咽 頭歯群があり, 咽頭骨に植立している。イワナで は咽頭下面正中部にも咽頭歯がある。またイワナ 属では前上咽頭菌はニジマス属の $3 \sim 4$ 倍歯数が 多い。

3. 鰓耙骨歯は鰓耙骨の大きさ，形態により発 達程度や分布状態に差がみられる。鰓亏隅角部の 鰓耙骨では鰓裂側の面に鰓耙骨歯が密に分布する 傾向がある。

4. マス類 5 種の鰓耙の鋸歯または小棘は組織 構造上, 歯であってニジマスの鰓耙骨茵と同一物 である。

\section{謝辞}

稿を終るにあたり，材料を提供して下さった水産 庁淡水区水産研究所日光支所の方々に謝意を表しま す。

\section{文献}

1）野村 稔：サケ科魚類の口腔にある分類形質に ついて. 魚類学雑誌, $2: 261-270,1953$.

2）野村 稔：サケ科魚類の口腔にある分類形質 について, II. 太平洋産サヶ科魚類. 魚類学雑 誌, $3: 232-236,1954$.

3）橋本 巌, 小寺春人, 井上孝二 : サヶ科魚類咽 頭の歯について (抄). 歯基礎誌, $17: 505$, 1975.

4) 橋本 巌, 後藤仁敏, 小寺春人, 井上孝二 : 二 ジマス (Salmo gairdueri irideus GibBons) の咽頭の 2 群の蒾について. 歯基礎誌, 18 : 349-361, 1976.

5) Tchernavin, V.: Notes on the chondrocranium and branchial skeleton of salmo. Proc. Zool. Soc., London, 108 B : 347-364, 1938.

6) Norden, C. R. : Comparative osteology of representative salmonid fishes, with particular reference to the grayling (Thymallus arcticus) and its phylogeny. J. Fish. Res. Bd. Canada, $18: 679-791,1961$.

7）太田康治：鰉鰌類の鰓耙について. 水産学会 報, $2: 261-266,1918$.

8）内田 亨, 松原喜代松：動物系統分類学, 第 9 巻 (上), 脊椎動物 (Ia) 魚類, 中山書店, 東 京, 1972.

9) 松原喜代松, 落合 明, 岩井 保: 魚類学(上) 和管全, 9. 恒星社, 東京, 1974. 
10) Suyehiro, Y.: A study on the digestive system and feedings habits of fish. Jap. Journ. Zool., $10: 1-303,1941$.

11）水谷秋俊, 欠谷正公, 井上敏治, 倉橋浩一: 鰓 蒾について (抄). 茵科医学, $25: 105,1962$.

12) 福田芳生：カムルチーChana argus (CANTOR) の鰓耙表面に密生する小棘う組繊学的観祭. 化 不研究会会誌, $11: 14-17,1976$.

13) Peyer, B. : Comparative Odontology, translated and edited by Zangerl, R., The Univ. of Chicago Press, Chicago \& London, 1968.

14）井上孝二, 橋本 巌, 小寺春人: 数種魚類の歯 の分布状態（抄）. 鶴見畨学， 1: 108，1975.

15) Nelson, G. J. : Gill arches of teleostean fishes of the family Clupeidae. Copeia, No. 2, 389-398, 1967.

16) Nelson, G. J. : The hyobranchial apparatus of teleostean fishes of the families Engraulidae and Chirocentridae. American Museum Novitates, No. 2410, 1-30, 1970.

\section{図 $7 \sim$ 図 24 の説明}

図 7 ヤマ（全長 $120 \mathrm{~mm}$ ) の口腔から食道付近の内腔の背側面。歯の輪郭を縁どって口腔の歯と咽頭歯の分 布を示す。

図 8 同上の腹側面。

図 9 図 7 の 線写真。矢印は後上咽頭歯群を示す。

困10 図 $80 X$ 線写真。矢印は下咽頭柬群。

四11 Oncorhynchus nerka ヒメマス, Salmo truttaブラウンマス, Salvelinus pulvius イワナ, Salv. fontinalis カ ワマスの咽頭背側面。歯の輪郭を縁どって咽頭番の分布を示す。

図12闰上の腹側面。

図13〜図21 咽頭の歯の分布と骨または骨格との関係を alizarin red 染色標本で示す。

図13ヒメマスの咽頭背側面。矢印は前上咽頭骨と前上咽頭歯。その下方で後上咽頭歯と後上咽頭骨が明瞭であ る。各鰓弓の骨の辺縁に沿って鰓耙骨がならび, 鰓耙骨に微細な鰓耙骨歯が植立している。

図14 ヒメマスの咽頭腹側面。矢印は下咽頭歯群を示す。

困15 ブラウンマスの咽頭背側面の右側半。太い矢印の上のものは前上咽頭歯をさし，下のものは後上咽頭蒾を 示す。細い矢印は鰓耙骨の骨の形成されない面を示し，ととには鰓耙骨歯は分布していない。

汹16 カワマスの咽頭背側面の右側半。矢印は前後の上咽頭歯。

図17 イワナの咽頭背側面。矢印は後上咽頭歯。その上方第 3 鰓弓の正中寄りに前上咽頭歯が多数みられる。

図18図17う右側半を拡大。太い矢印は前後の上咽頭歯を示し, 細い矢印は鰓耙骨の基底部の突起である。同様 の突起が前方にもあり，短く内，外側に突出している。

図19 イワナの咽頭腹側面。下咽頭歯はイワナでは咽頭後半部（下方の矢印）のほか, 前半鰓腔部の正中部にも みられる (上方の矢印)。

四20 困19つ鰓腔部の正中部付近を拡大して，咽頭㐘を示す。

困21 ヤマメの第 1 鰓弓咽頭面隅角部の鰓耙骨。咽頭腔側と鰓裂側の両面で鰓耙省柬の分布を示す。原倍率× 25 \%

四22 下咽頭歯の光顕写真。ヤマメ, 全長 $112 \mathrm{~mm}$, 矢状断, $\mathrm{HE}$ 染色, 原倍率 $\times 70$ 。

$\mathrm{D}$ : 象牙質, $\mathrm{P}$ : 歯髄, $\mathrm{PD}:$ 歯足骨

B : 下咽頭骨, C 5 : 第 5 角鰓骨

咽頭骨と角鰓骨は癒合していない。

困23イワナの咽頭腹側面正中部の下咽頭蒾の光顕写真。全長 $120 \mathrm{~mm}$, 体重 $20 \mathrm{~g}$, 矢状断, HE染色, 原倍率 $\times 50$ 。 $\mathrm{T}$ ：下咽頭歯， $\operatorname{tg}$ : 歯胚, B : 咽頭骨, BP2 : 第 2 基鰓骨, * : artifact

咽頭骨は基鰓骨の骨化した部分と骨小柱により随所で瘾合している。

四24 鰓耙骨歯とその㐘胚の光顕写真。ヤマメ, 全長 $12 \mathrm{~mm}$, 体重 $15 \mathrm{~g}$, 矢状断, Azan 染色, 原倍率 $\times 280$ 。 GRT : 鰓耙骨歯, GRtg：鰓耙骨歯の歯胚, PD : 歯足骨, GRB：鰓耙骨。

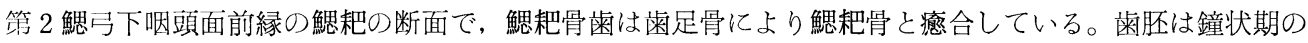
もので，その上皮性部分は粘膜上皮層に限局している。エナメル牙細胞と象牙牙細胞が分化して，象牙質 の形成がはじまっている。 


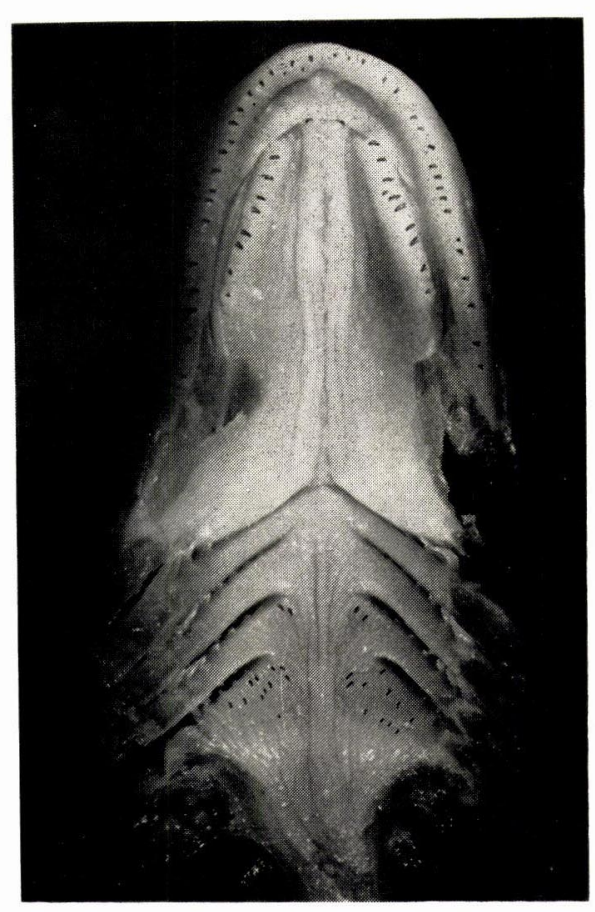

四 7

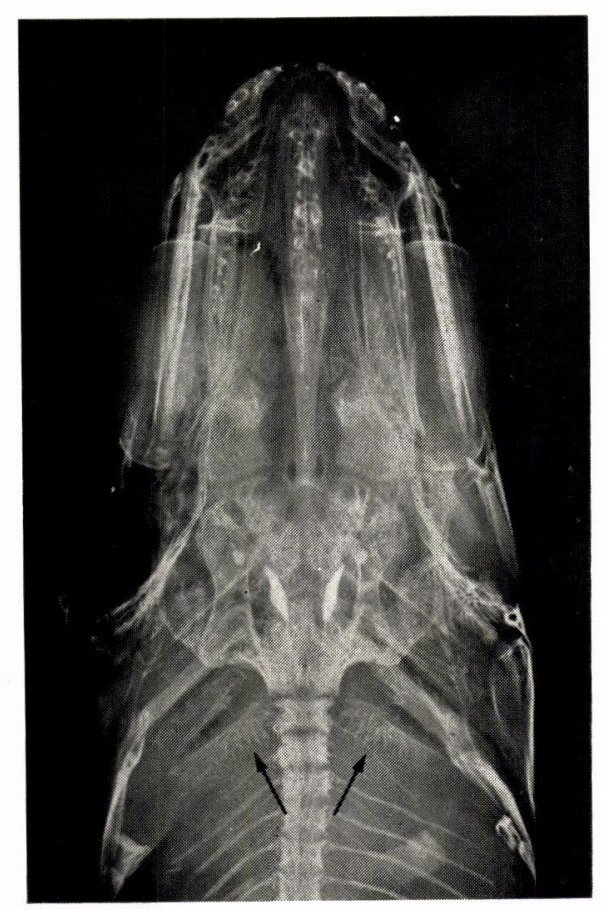

図 9

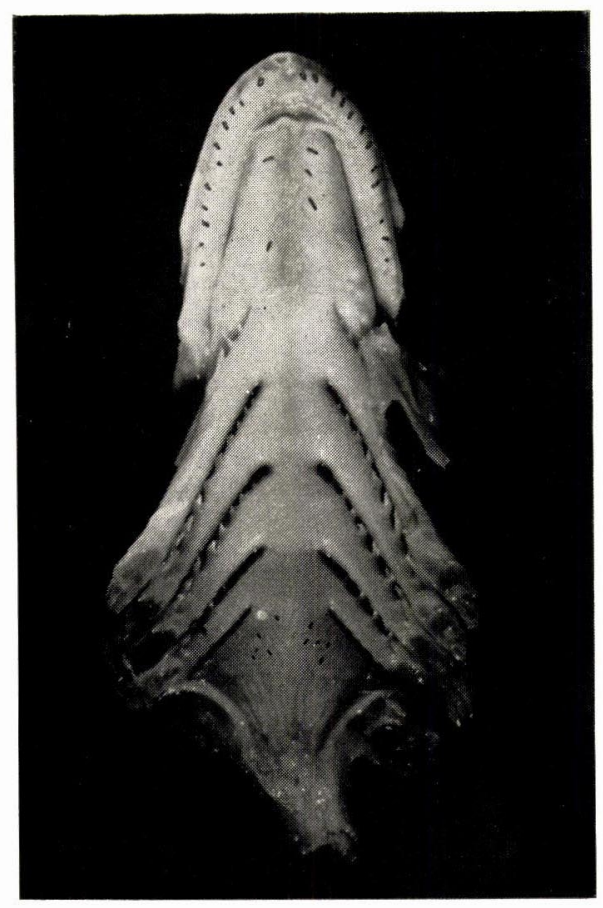

図 8

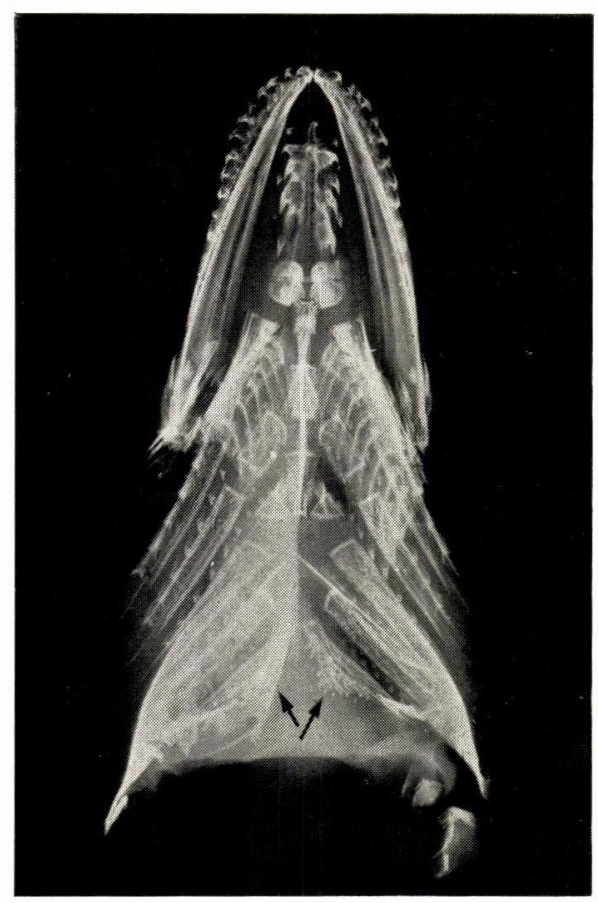

図 10 


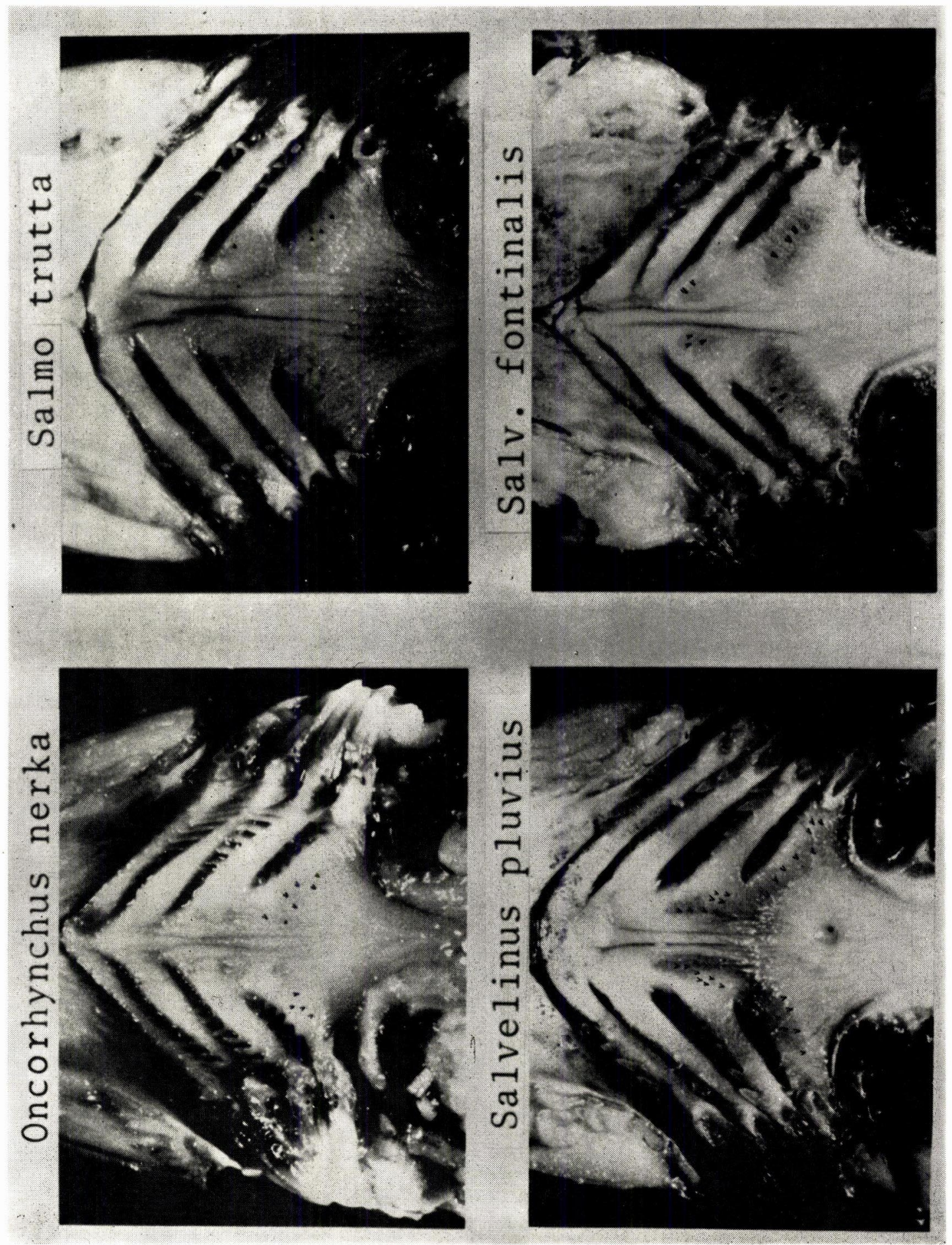




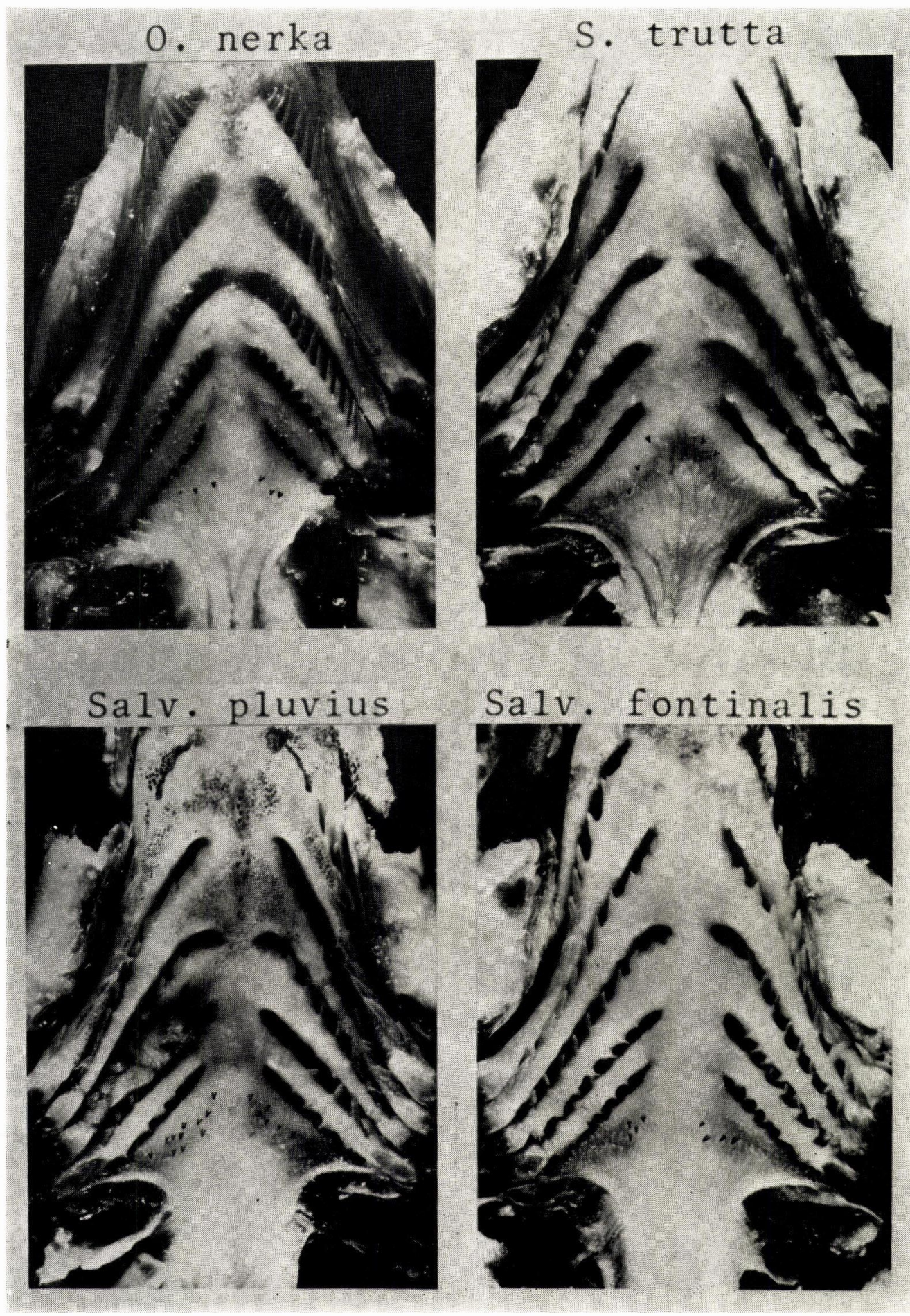

図 12 


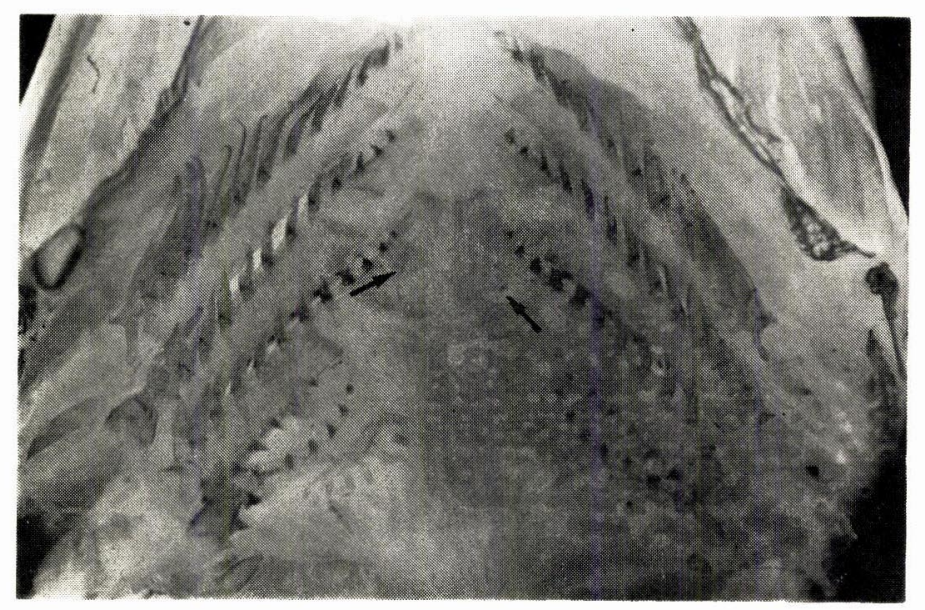

図 $\quad 13$

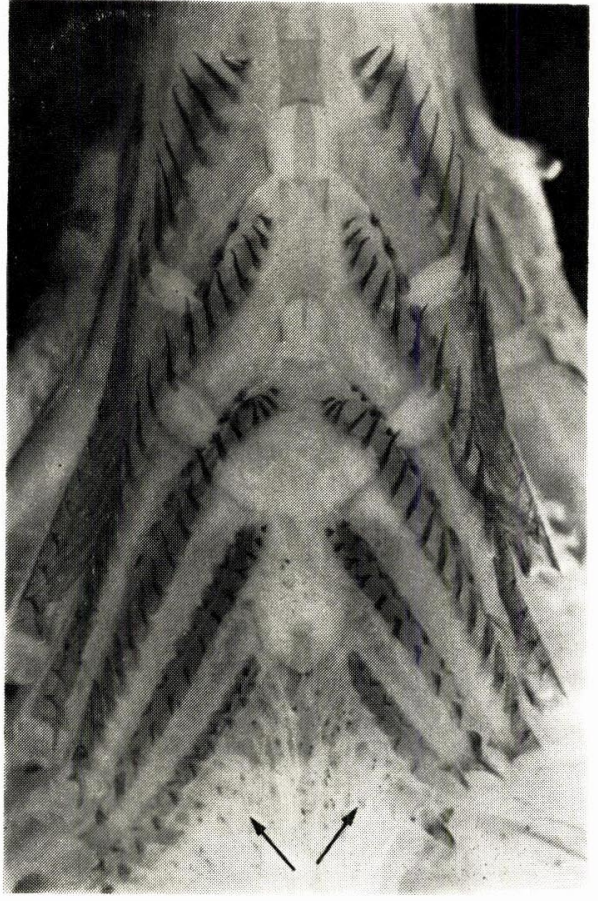

図 14

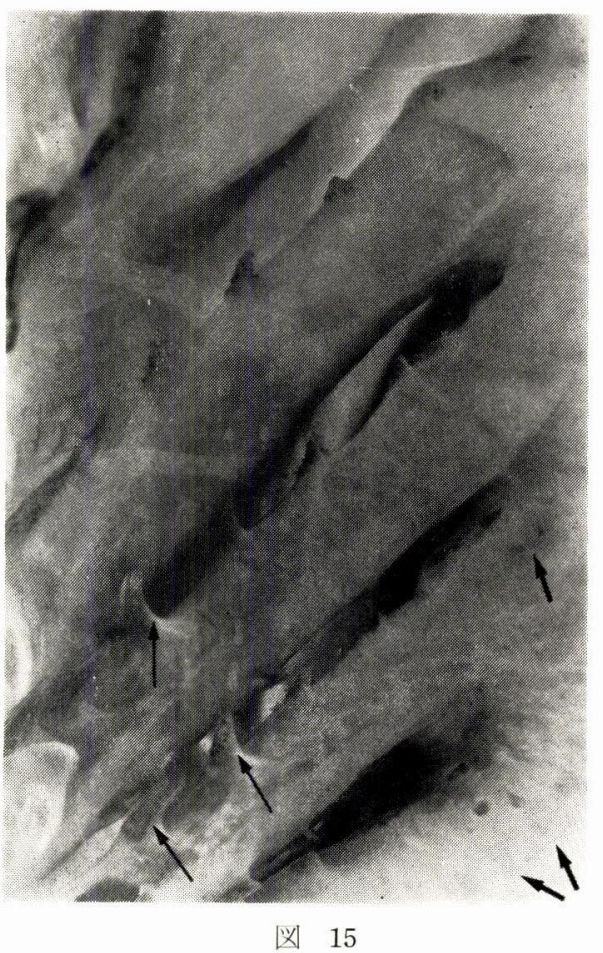

(147) 

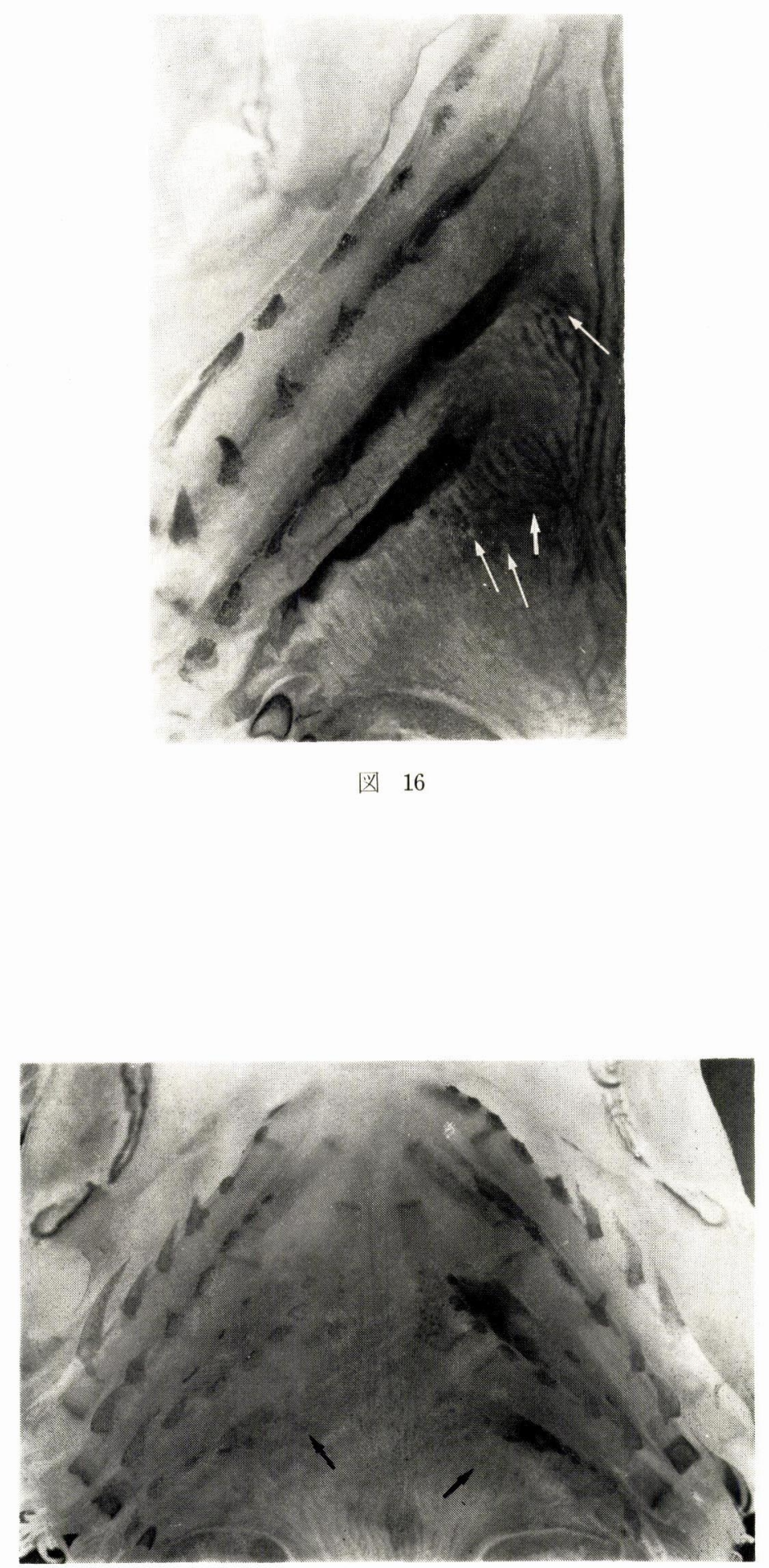

図 17

(148) 


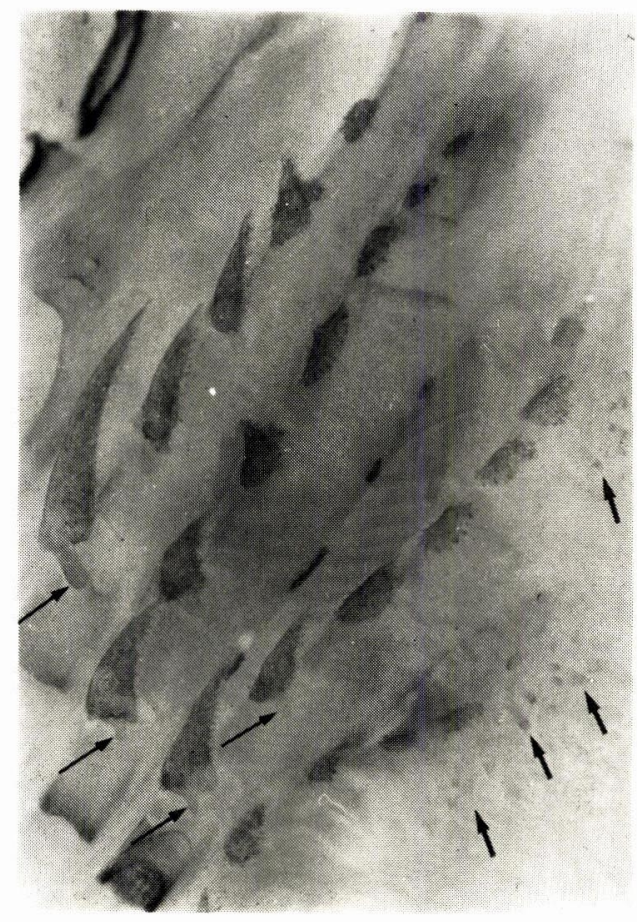

四 18

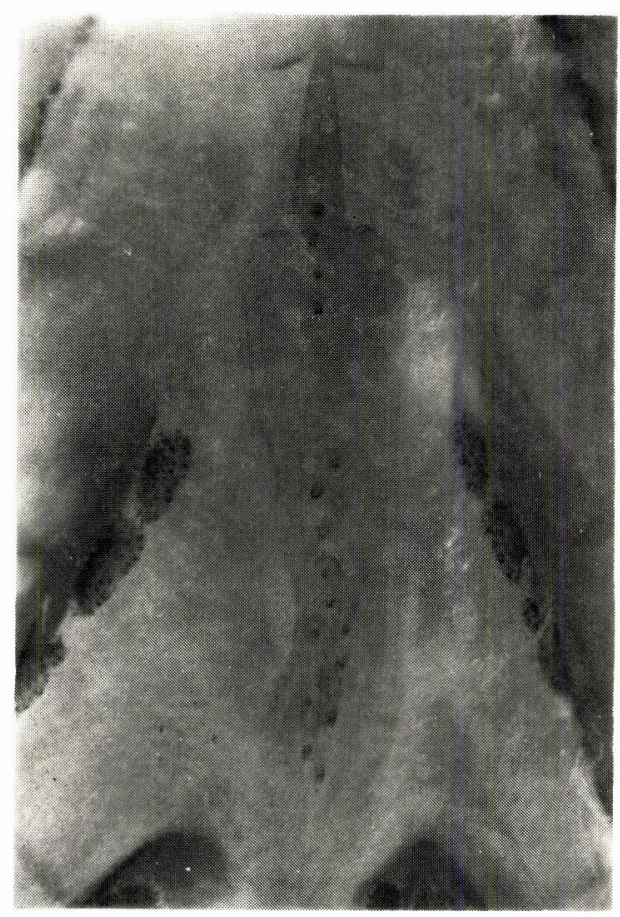

図 20

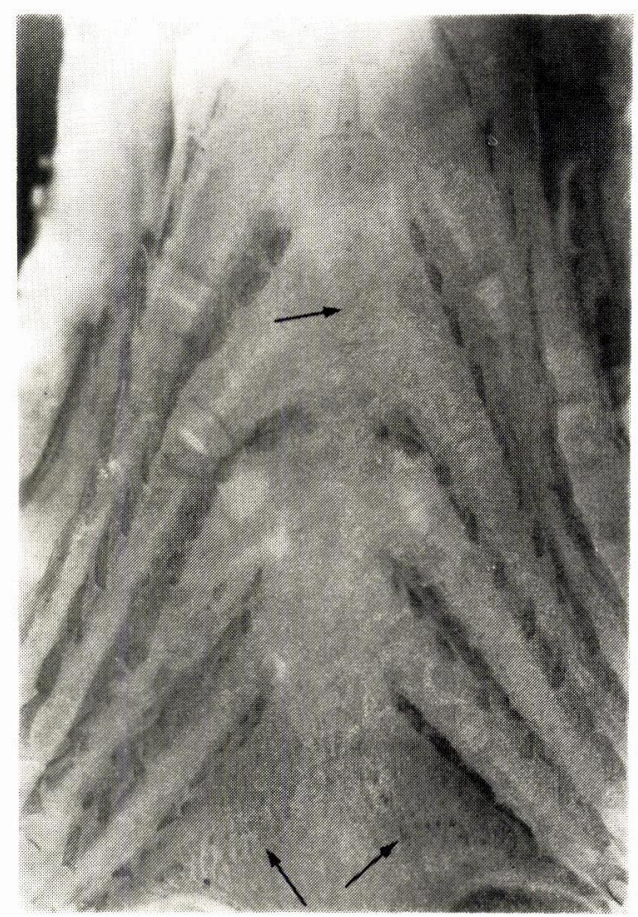

図 19

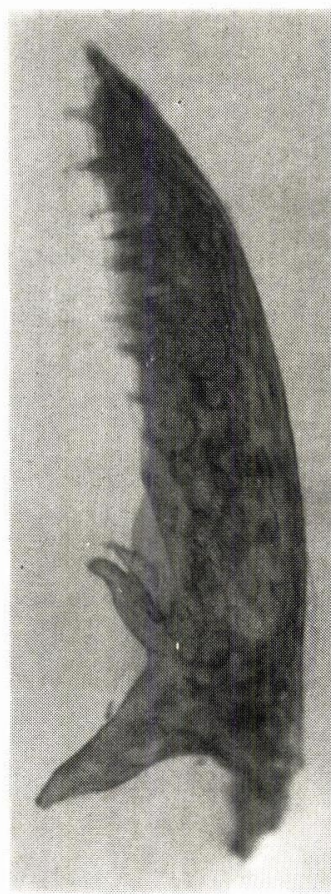

(咽頭腔側)

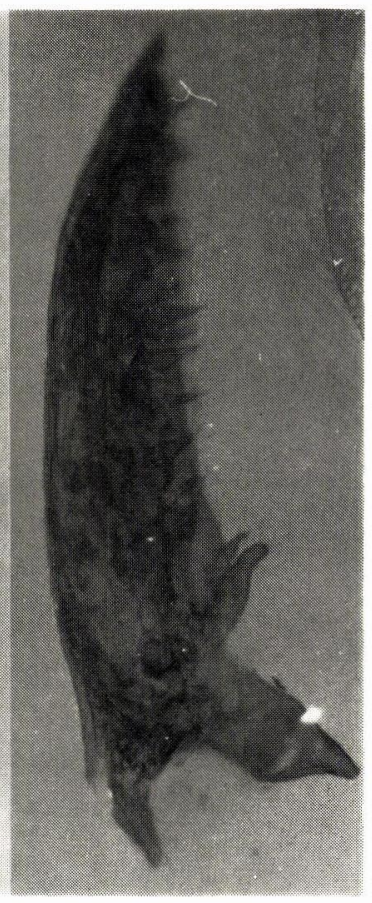

（鰓裂側） 


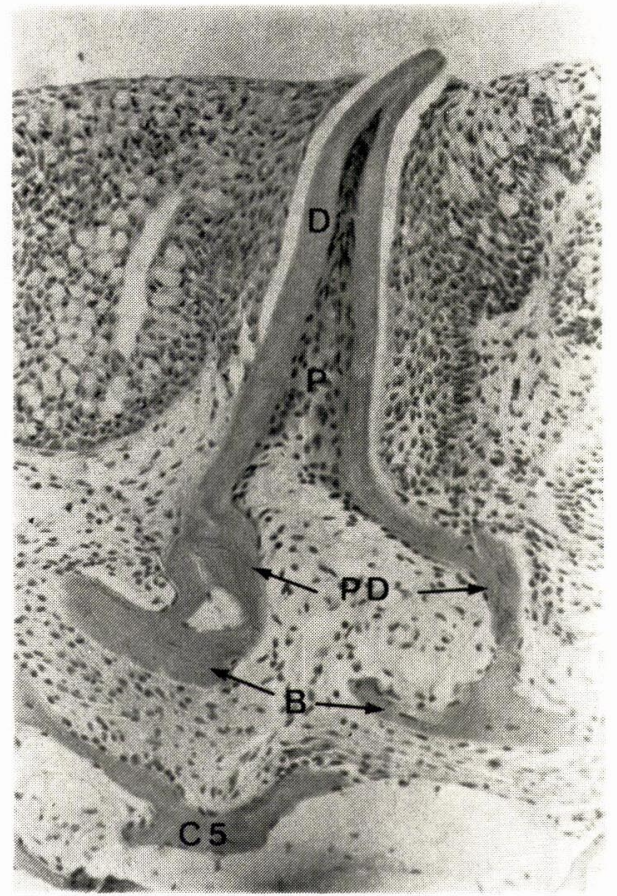

図 22

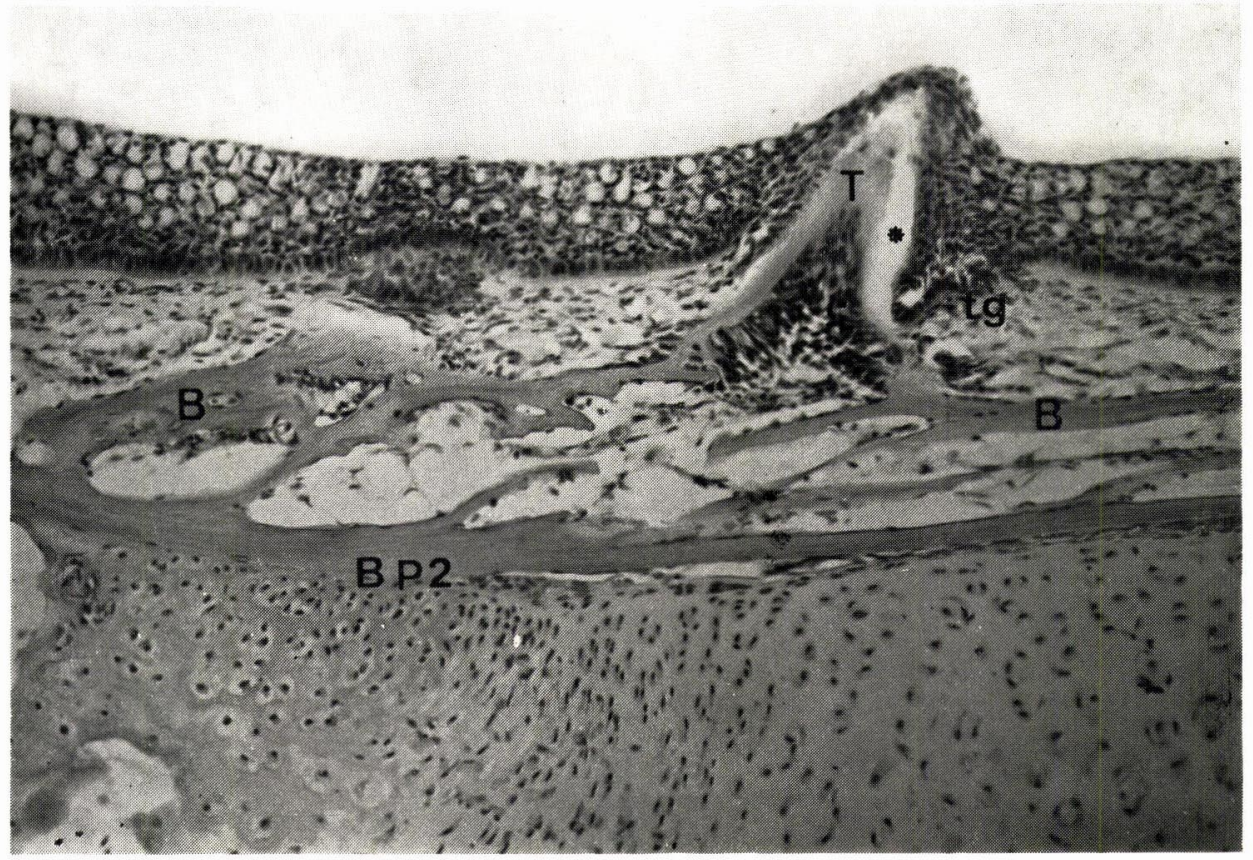

図 23

(150) 


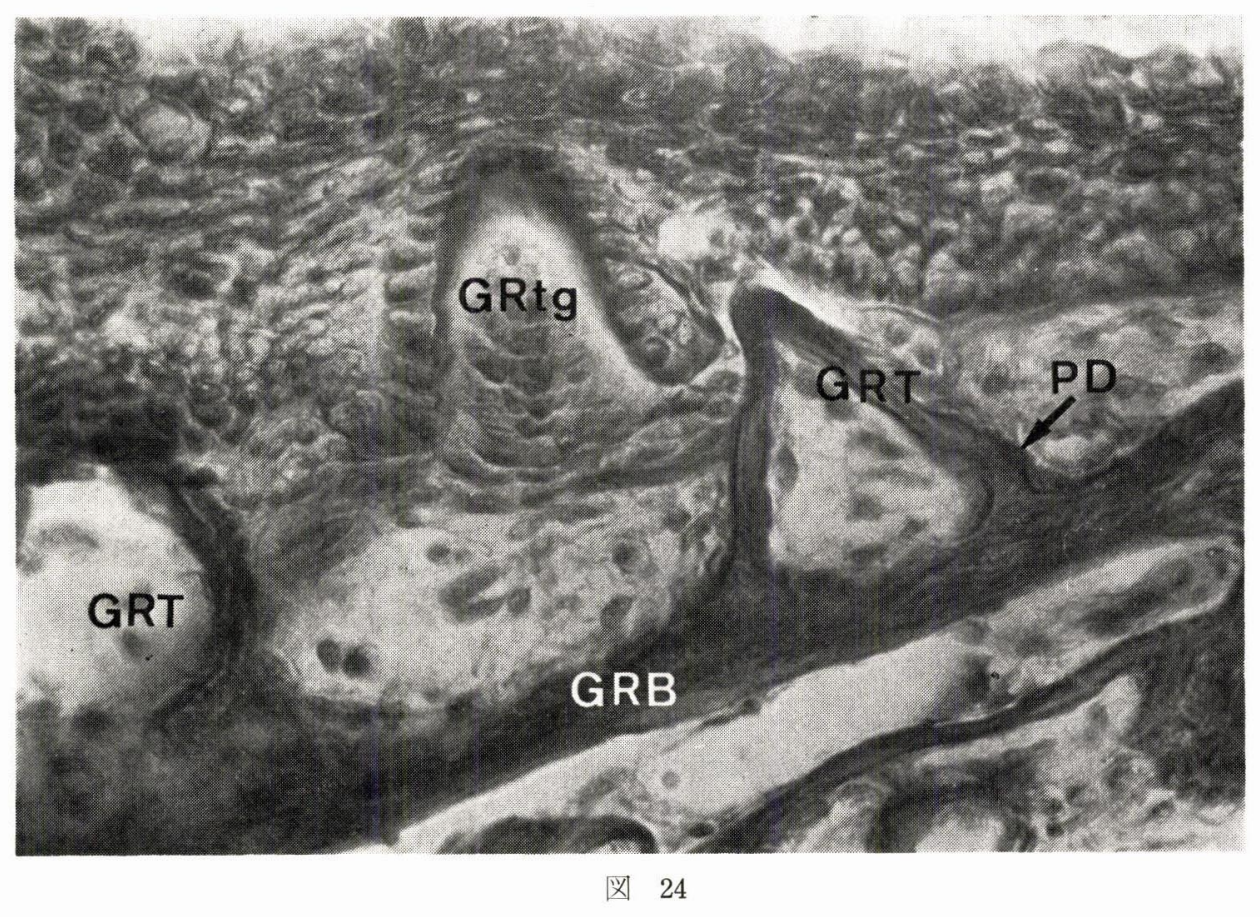

